УдК 334.021.1

\title{
РОЗВИТОК ІННОВАЦІЙНОї ДІЯЛЬНОСТІ В УМОВАХ ЦИФРОВІЗАЦІї
}

\section{INNOVATIVE ACTIVITY DEVELOPMENT IN THE CONDITIONS OF DIGITALIZATION}

\author{
Тимошенко Наталія Юріївна \\ кандидат економічних наук, \\ Національний технічний університет України \\ «Київський політехнічний інститут імені Ігоря Сікорського» \\ ORCID: https://orcid.org/0000-0002-1055-5355 \\ Шабанова Марія Андріївна \\ студентка, \\ Національний технічний університет України \\ «Київський політехнічний інститут імені Ігоря Сікорського» \\ ORCID: https://orcid.org/0000-0002-9718-2706
}

\author{
Tymoshenko Nataliia, Shabanova Mariia \\ National Technical University of Ukraine \\ «lgor Sikorsky Kyiv Polytechnic Institute»
}

\begin{abstract}
Стаття присвячена актуальним питанням визначення стану розвитку інноваційної діяльності в умовах цифррової трансформації економіки. Цифровізацію економіки та життя суспільства можна вважати загальним світовим трендом і Україна намагається долучатись до цього процесу. У роботі проаналізовано особливості розвитку та фрункціонування інноваційної діяльності в Україні за період 2012-2019 років, зокрема, наведено дані щодо динаміки витрат та структури ффінансування інноваційної діяльності, основних показників виконання науково-дослідних робіт, секторів діяльності, що залучені її впровадження. У статті проаналізовано затверджені цілі сталого розвитку для України та здійснено прогнозування можливостей їх виконання. Запропоновано заходи щодо активізації розвитку інноваційної діяльності в умовах цифровізації.
\end{abstract}

Ключові слова: інновації, інноваційна діяльність, цифровізація, діджиталізація, цифрові інновації, цифрова трансфрормація економіки.

Статья посвящена актуальным вопросам определения состояния развития инновационной деятельности в условиях цифровой трансформации экономики. Цифровизацию экономики и жизни общества можно считать общим мировым трендом и Украина старается приобщаться к этому процессу. В работе проанализированы особенности развития и функционирования инновационной деятельности в Украине за период 2012-2019 годов, в частности, приведены данные о динамике расходов и структуре фринансирования инновационной деятельности, основных показателях выполнения научно-исследовательских работ, секторах деятельности, привлеченных для ее внедрения. В статье проанализированы утвержденые цели устойчивого развития для Украины и осуществлено прогнозирование возможностей их выполнения. Предложены меры по активизации развития инновационной деятельности в условиях цифровизации.

Ключевые слова: инновации, инновационная деятельность, цифровизация, диджитализация, цифровые инновации, цифровая трансформация экономики.

Innovations and digital technologies provides unique opportunities in the process of economic development, increasing the country's competitiveness and quality of life. The world economy development requires the intensification and significant expansion of innovations. Digitalization is becoming a new basis for the functioning and development of innovations. It determines the need for research of the digital economy and its impact on innovative development, which emphasizes the relevance of this study. The study of scientific professional literature showed the difference in views of scientists on the concept, components and essence of the term "digitization". In foreign practice, in the broadest sense, the process of digitalization of the economy is usually understood as a socio-economic transformation initiated by the mass introduction and assimilation of digital technologies, it means technolo- 
gies for creating, processing, exchanging and transmitting information. According to the Concept of Development of Digital Economy and Society of Ukraine for 2018-2020, it is noted that the main goal of digitalization is to achieve digital transformation of existing and creation of new sectors of the economy, as well as transformation of life into new more efficient and advanced. The purpose of the article is to analyze the development of innovations in Ukraine in the context of digitalization, highlighting trends and features of this process. The digitalization of the economy and society can be considered as a general global trend and Ukraine is trying to join this process. The paper analyzes the features of development and functioning of innovations in Ukraine for the period 2012-2019, in particular, provides data on the dynamics of costs and funding structure of innovations, as well as the main indicators of research and development and key sectors involved in its implementation. The article analyzes the approved Goals of Sustainable Development for Ukraine, as well as the Global Innovation Index and forecasts the possibilities for their achievment. The measures to intensify the development of innovation in the context of digitalization are proposed in the paper.

Keywords: innovations, innovative activity, digitalization, digital innovations, digital transformation of economy.

Постановка проблеми. Інновації та цифррові технології надають унікальні можливості в процесі розвитку економіки, підвищують конкурентоспроможність країни та якість життя суспільства. Розвиток світової економіки вимагає активізації та значного розширення масштабів інноваційної діяльності. Нові можливості взаємодії держави, економіки та суспільства, що базуються на глобальному проникненні діджиталізації в усі сорери життєдіяльності людини, зумовлють необхідність наукового дослідження цифрової економіки та її впливу на інноваційний розвиток, що підкреслює актуальність даного дослідження.

Аналіз останніх досліджень і публікацій. Визначний вклад у дослідження інноваційної діяльності, а також процесу цифровізації економіки внесли такі науковці, як В. Геєць, С. Ілляшенко, В. Ляшенко, Д. Стеченко, П. Самуельсон, Д. Тапскотт, Л. Федулова, Й. Шумпетер та інші вчені. Проте у науковій літературі недостатньо висвітленими залишаються особливості розвитку інноваційної сорери в умовах цифрровізації економіки та життя суспільства.

Виділення невирішених раніше частин загальної проблеми. Функціонування економіки характеризується певними особливостями, що визначають можливості економічних суб'єктів, чинники їх розвитку, ефективність діяльності та впливають на подальше зростання. В наш час, особливу значимість набуває такий вплив у сорері інноваційної діяльності. Цифрровізація стає новою основою фрункціонування та розвитку інноваційної сфрери.

Постановка завдання. Метою статті $\epsilon$ аналіз розвитку інноваційної діяльності в Україні в умовах цифровізації, виділення тенденцій та особливостей даного процесу.

Виклад основного матеріалу дослідження. Останнім часом цифрровізація $€$ фрундаментом у зростанні світової економіки. Цифррові технології являються потужною індустрією, сильним ринком та інтеграційною платфрормою, що забезпечують взаємодію та конкурентоспроможність всіх інших сорер та галузей економіки. Високотехнологічність виробництва, здатність до провадження інновацій та модернізація різних секторів країни, на основі сучасних технологій мають стати пріоритетним рішенням для успішного зростання та процвітання економіки України.

Дослідження наукової фрахової літератури показало відмінність поглядів науковців на поняття, складові та сутність терміну «цифрровізація». У зарубіжній практиці у найширшому сенсі під процесом цифровізації економіки зазвичай розуміється соціально-економічна трансформація, ініційована масовим упровадженням і засвоєнням цифрових технологій, тобто технологій створення, обробки, обміну та передачі інформації [1].

Згідно Концепції розвитку цифрової економіки та суспільства України на 2018-2020 роки, зазначається, що основна мета цифровізації полягає у досягненні цисррової трансформації існуючих та створенні нових галузей економіки, а також трансфрормації ссрер життєдіяльності у нові більш есрективні та сучасні. Такий приріст є можливим лише тоді, коли ідеї, дії, ініціативи та програми, які стосуються цифровізації, будуть інтегровані, зокрема, в національні, регіональні, галузеві стратегії і програми розвитку. Цифровізація $є$ визнаним механізмом економічного зростання завдяки здатності технологій позитивно впливати на ефективність, результативність, вартість та якість економічної, громадської та особистої діяльності [2].

Однією основних характеристик особливостей інноваційного розвитку країни $є$ динаміка структури загального обсягу витрат на інноваційну діяльність, що відображає пріоритети у розподілі коштів (рис. 1).

3 рисунку 1 можна зробити висновок, що кожного року найбільша частина витрат спрямовується витрати на придбання машин, обладнання та програмного забезпечення. Так, станом на 2019 рік 


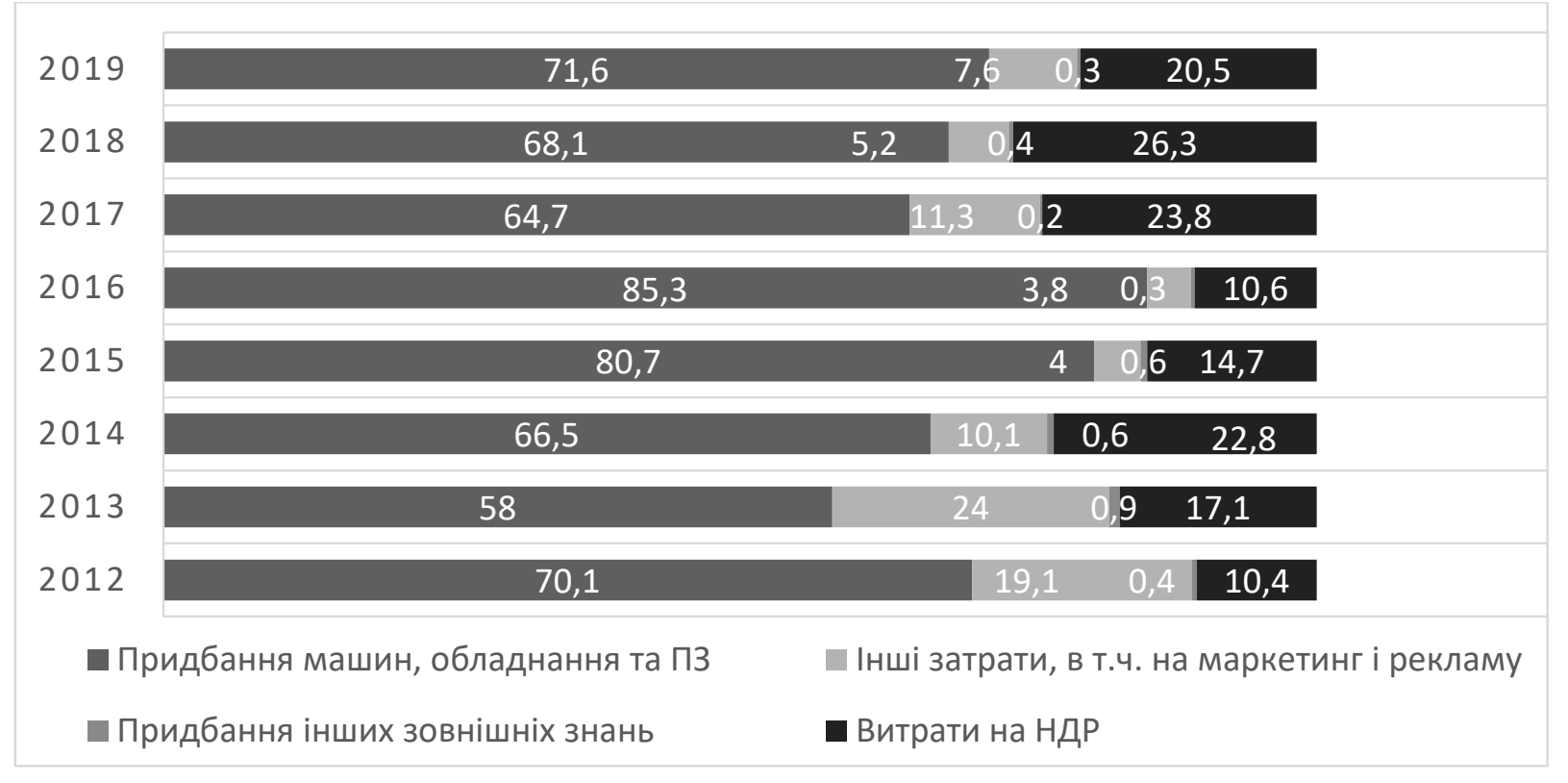

Рис. 1. Динаміка структури загального обсягу витрат за напрямами інноваційної діяльності за 2012-2019 рр.

Джерело: складено за джерелом [3]

витрати підприємств на інновації загалом склали 14220,9 млн. грн. 3 них 71,6\% витрат (10185,11 млн. грн) склали придбання машин, обладнання та програмного забезпечення, 20,5\% (2918,85 млн. грн) - кошти на внутрішні та зовнішні науково-дослідні розробки, 7,6\% (1079,45 млн. грн) було розподілено на інші роботи, пов'язані зі створенням та впровадженням інновацій (інші витрати) та 0,3\% (37,49 млн. грн) витрат склало придбання інших зовнішніх знань. Частка витрат на придбання машин, обладнання та програмного забезпечення порівняно з 2018 р. зросла на 3,5\%. Разом з тим, частки витрат на науководослідні розробки зменшились на $5,8 \%$, а частка витрат на придбання інших зовнішніх знань залишилась майже незмінно низькою $(-0,1 \%)$. У той же час частка витрат на інші затрати, а також на маркетинг і рекламу зросла на 2,4\%.

У порівнянні 32018 р. обсяг фрінансування інноваційної діяльності зріс до 14220,9млнгрн, при цьому частка фрінансування інноваційної діяльності у співвідношенні до ВВП залишилася на рівні 0,3\% (рис. 2).

Основним джерелом срінансування інновацій у 2019 р. залишаються власні кошти підприємств - 12474,9 млн грн (або 87,7\% загального обсягу фрінансування інновації). Кошти державного бюджету отримали 6 підприємств, загальний обсяг яких становив 556,5 млн грн (3,9\%); кошти іноземних інвесторів отримали 3 підприємства в обсязі 42,5 млн грн (0,3\%); обсяг коштів з інших джерел становив 1147,0 млн грн (8,1\%) [4]. Динаміка зміни структури фрінансування інноваційної діяльності подано на рис. 3.

Успішне зростання сучасного підприємства чи організації в умовах цисрровізації тісно пов'язане 3 інноваційною діяльністю. Актуальним напрямом даної діяльності $€$ науково-дослідні роботи, так як саме вони $\epsilon$ невід'ємною її частиною в процесі створення будь-яких інновацій. Тому, доцільно розглянути сектори діяльності, які здійснювали НДР, в Україні за останні роки (рис.4).

3 рис. 4 можемо зробити висновок, що загальна кількість організацій за досліджуваний період $€$ майже незмінною. Основну частину науково-дослідних робіт здійснюють державний та підприємницький сектори, що свідчить про їхній суттєвий вклад в розвиток інноваційної діяльності України. Сектор вищої освіти має сталий низький рівень серед досліджуваних секторів економіки, який показує недостатню інноваційну активність в цій сорері. У таблиці 1 розглянуто більш детально основні показники НДР у таблиці 1.

За табл. 1 варто звернути увагу на те, що в 2020 році порівняно із 2015 роком кількість працівників, задіяних у виконанні наукових досліджень і розробок зменшилась. На нашу думку, це пов'язано зі зменшенням частки витрат на НДР у ВВП та карантинними обме- 


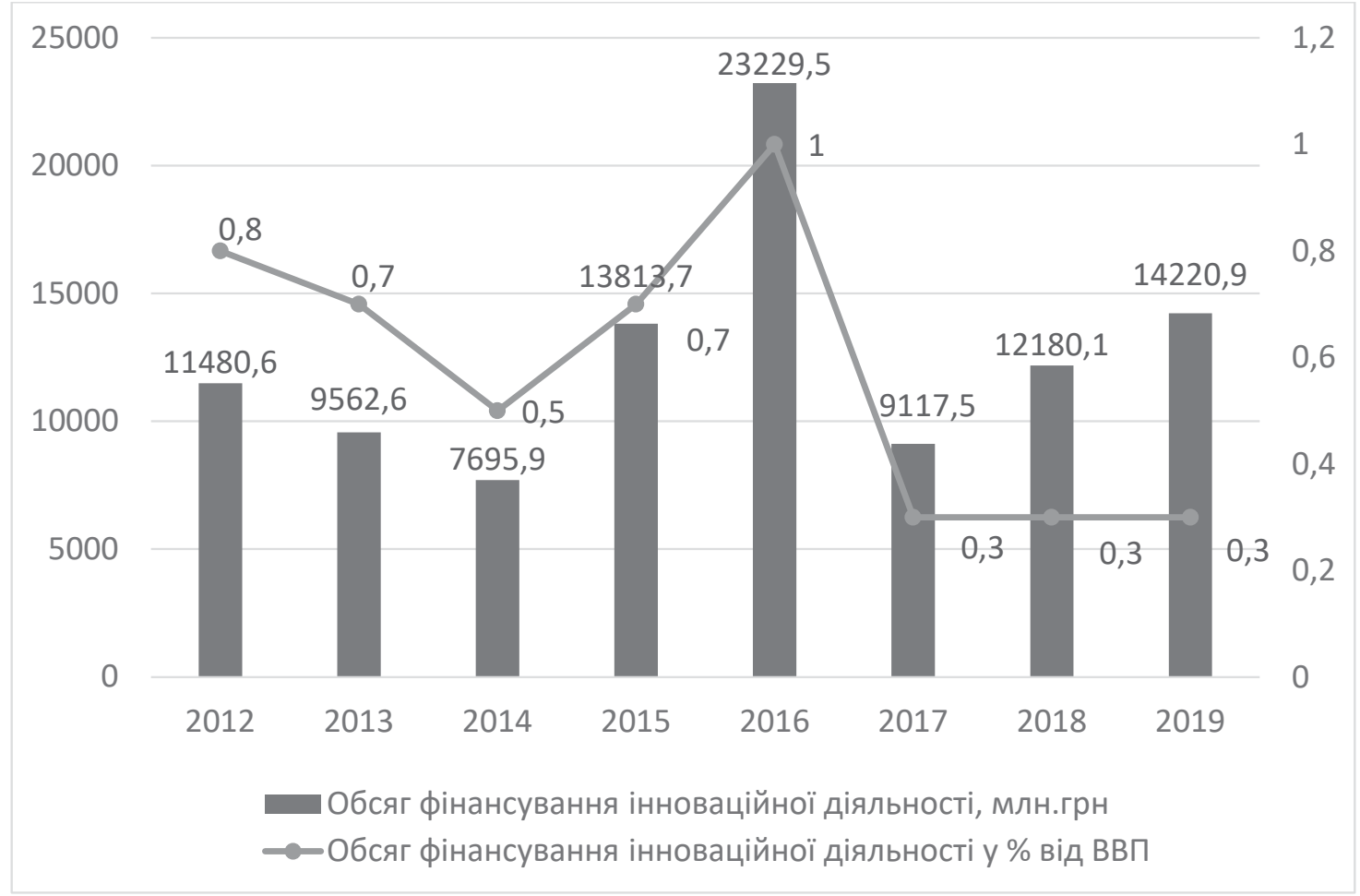

Рис. 2. Динаміка обсягу фінансування інноваційної діяльності за 2012-2019 рр.

Джерело: складено за джерелом [3]

женнями, що плинула на всі сорери економіки та життя суспільства. На жаль, можна простежити тенденцію до спаду частки чисельності працівників за період 2015-20120 роки з 122504 до 78860 осіб.

Відповідно до Цілей сталого розвитку України [5] одним 3 пріоритетних завдань $є$ ство- рення фрінансової та інституційної системи (інноваційної інфрраструктури), що забезпечуватимуть розвиток наукових досліджень та науково-технічних (експериментальних) розробок - завдання 9.5. В межах виконання даного завдання заплановано збільшити частку витрат на НДР, що у до 2020 року мала

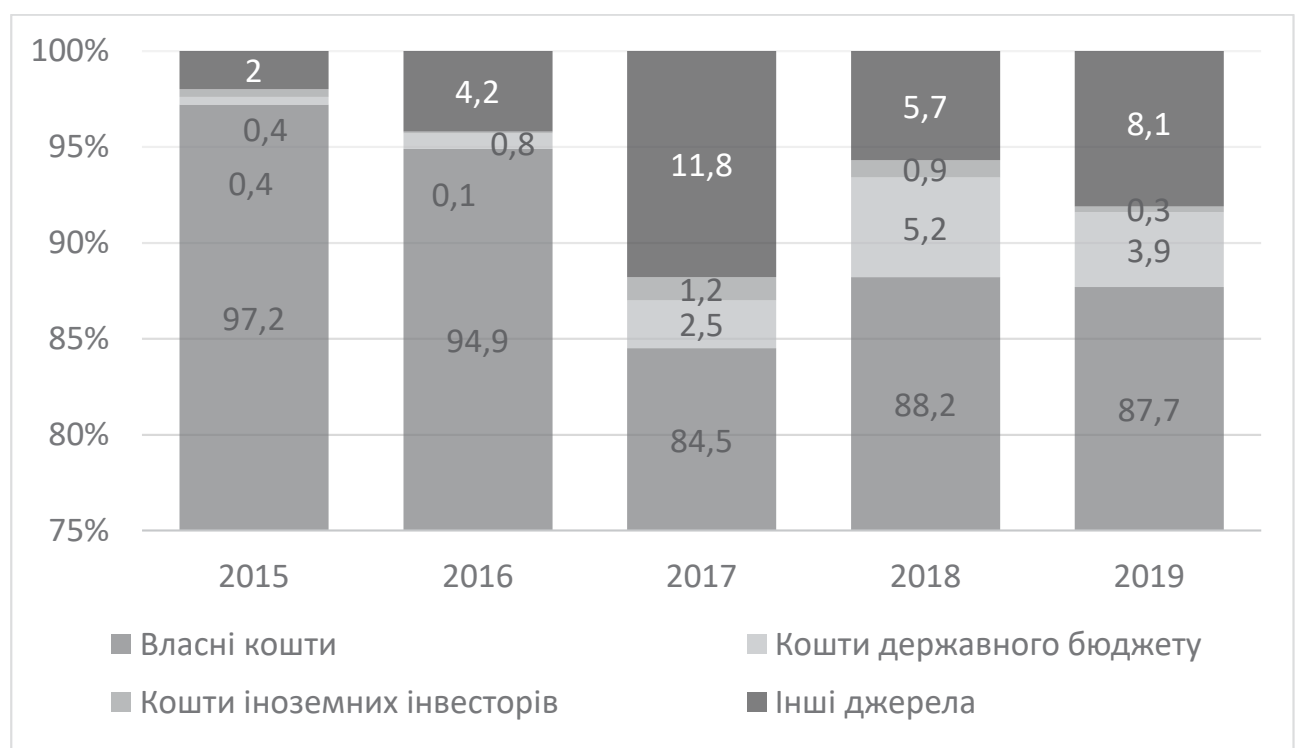

Рис. 3. Динаміка структури фінансування інноваційної діяльності за джерелами за 2015-2019 рр.

Джерело: складено за джерелом [3] 


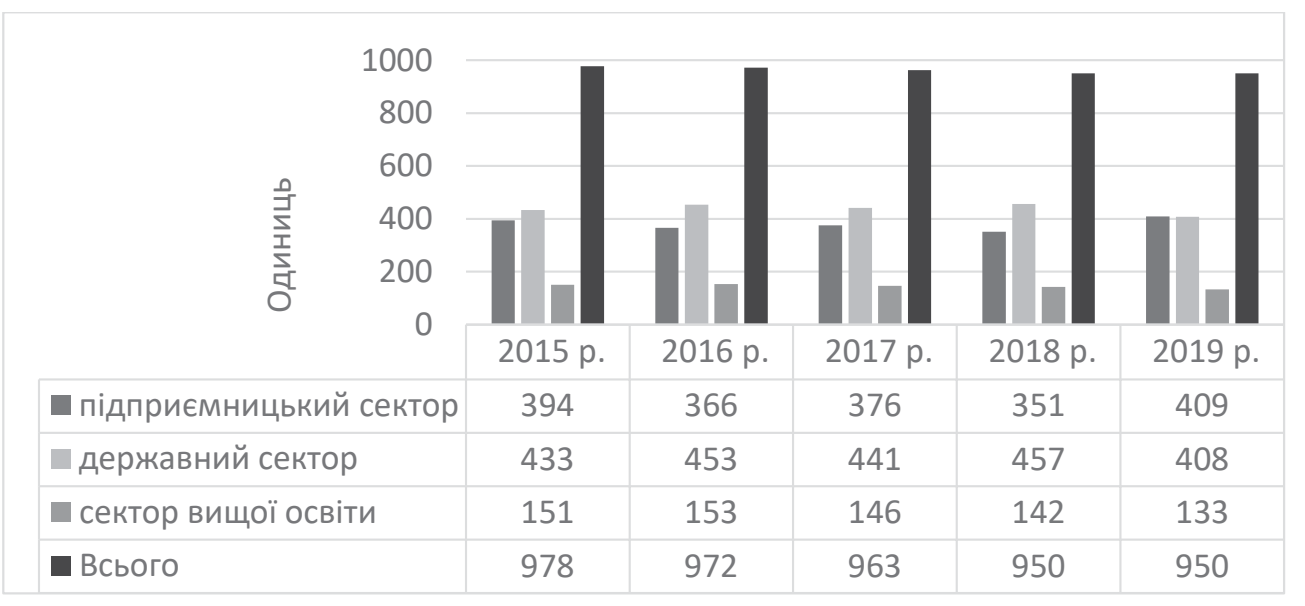

Рис. 4. Кількість організацій, які здійснювали НДР, за секторами діяльності

Джерело: складено за джерелом [3]

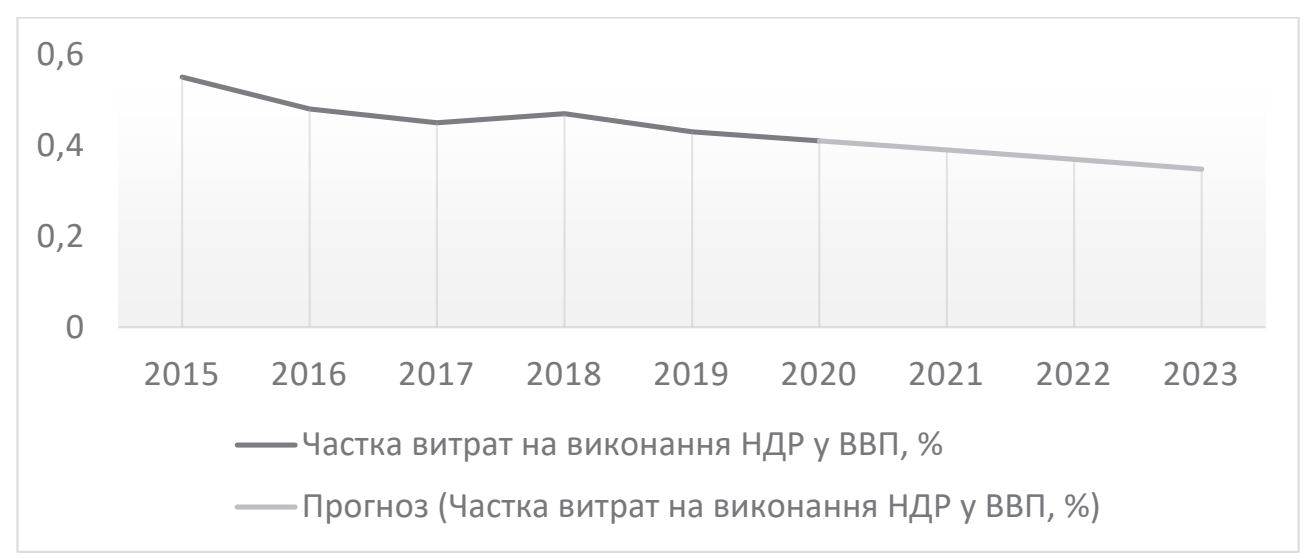

Рис. 5. Прогнозні значення частки витрат на виконання НДР Джерело: розроблено автором

б становити не менше $1,5 \%$, а до 2030 року зрости до 3\% у ВВП. Тому доцільно здійснити прогноз частки витрат на НДР на найближчі роки (рис. 5).

Виходячи 3 результатів моделювання, $€$ загроза того, що Україна вірогідніше за все не зможе виконати поставлене завдання 9.5.1, а також завдання 9.6 (забезпечити доступність Інтернету, особливо у сільській місцевості 100 абонентів на 100 жителів у 2030 році) відповідно до затверджених Цілей Сталого Розвитку країни.

Проте, є перспективи того, що з огляду на складові субіндексу Україна зможе досягти

Основні показники виконання науково-дослідних робіт

Таблиця 1

\begin{tabular}{|c|c|c|c|}
\hline Рік & $\begin{array}{c}\text { Кількість працівників, } \\
\text { задіяних у виконанні } \\
\text { НдР, осіб }\end{array}$ & $\begin{array}{c}\text { Витрати } \\
\text { на виконання ндР, } \\
\text { млн.грн }\end{array}$ & $\begin{array}{c}\text { Частка витрат } \\
\text { на виконання НДР у ВВп, } \\
\text { \% }\end{array}$ \\
\hline 2015 & 122504 & 11003,6 & 0,55 \\
\hline 2016 & 97912 & 11530,7 & 0,48 \\
\hline 2017 & 94274 & 13379,3 & 0,45 \\
\hline 2018 & 88128 & 16773,7 & 0,47 \\
\hline 2019 & 79262 & 17254,6 & 0,43 \\
\hline 2020 & 78860 & 17022,4 & 0,41 \\
\hline
\end{tabular}

Джерело: складено за джерелом [3] 
завдання 8.1.4 - 40 місце у рейтингу за Глобальним інноваційним індексом, адже станом на 2020 рік - країна посіла 45 місце [6], увійшовши в топ-2 країн своєї групи та перевершивши прогнози розвитку (на 2020 р. планувалось 50 місце).

Впровадження цифрових інновацій впливає на всі сорери діяльності, а особливо на найбільш провідні галузі в економіці. Завдяки спрощенню технологічних процесів, розширюється та персоніфікується продуктова пропозиція на сроні спрощення доступу споживачів до неї. Інновації також дозволяють підвищувати ефективність бізнесу, адже нові рішення допомагають суттєво зменшувати собівартість залучення і обслуговування клієнтів, оцінювати і попереджати існуючі й нові ризики, знаходити нові джерела доходу тощо.

В умовах пандемії коронавірусу більшого успіху досягають ті економіки, які $€$ інтегрованими в безконтактну цифррову систему. Тому цифрровізацію можна вважати одним з чинників підвищення темпу економічного зросту, а також конкурентоспроможності країни в цілому. Зростання викликів для світової спільноти, розвиток демократичних свобод та різкий перехід до цифрової економіки мають прямий зв'язок із діджиталізацією та трансформацією економіки. Світова цифрровізація вже зараз фрормує значні виклики та загрози для всього світу.

В наш час цифрровізація інноваційної діяльності знижує інорормаційні та організаційні витрати економічних суб'єктів за допомогою багаторазового збільшення інфрормаційного простору, а також створення інфрормаційних продуктів, доступних широкому колу споживачів. Це спрощує та прискорює пошук та обробку інфрормації, її аналіз та обмін нею, в наслідок чого скорочується тривалість інноваційного лагу та активізується взаємодія суб'єктів інноваційного процесу.

3 метою активізації інноваційної діяльності в Україні вбачається необхідність розробки впорядкованих засобів взаємодії учасників інноваційного процесу, розвиток інфраструктури інноваційної діяльності та вироблення механізмів інноваційного розвитку регіонів, які спонукатимуть до підвищення рівня регіональної конкурентоспроможності. В умовах цифрровізації розвитку інноваційної діяльності це означає формування системи установ, здатних впроваджувати та масштабувати інновації, створюючи тим самим нові регіональні ринки високотехнологічних продуктів і послуг.

Висновки. Отже, виходячи з проведеного дослідження, можна дійти висновку, що на даний момент цифрровізація, хоча й є одним 3 чинників розвитку інноваційної діяльності, проте на разі має низький вплив та не активізує процеси у цій сорері. Причинами цього $€$ нестабільна інноваційна політика держави, відсутність національної інноваційної системи, розрізненість інтересів учасників інноваційного процесу, брак прозорих механізмів реалізації інновацій та низький попит на них на внутрішньому ринку. Відсутність достатнього фрінансування інноваційної сорери та дієвих стимулів до впровадження інноваційних процесів для підприємств, спричиняє спад інтересу до інноваційних розробок, а також зменшення кількості фрахівців, задіяних у науково-дослідних роботах.

На нашу думку, запорука успішного впровадження цисрових інновацій полягає у високому рівні цифррової грамотності громадян, компаній та уряду, а також дієвих механізмах їх взаємодії. Можна стверджувати, що наявний в Україні інтелектуальний потенціал створює необхідні передумови для активізації інноваційної діяльності на основі цифррових інновацій та переходу на більш високий технологічний рівень розвитку. 3 цією метою вбачається необхідність розробки впорядкованих засобів взаємодії учасників інноваційного процесу та розвиток інфрраструктури інноваційної діяльності регіонів, які спонукатимуть до підвищення рівня регіональної конкурентоспроможності та стимулюватимуть залучення до інноваційного процесу.

\section{СПИСОК ВИКОРИСТАНИХ ДЖЕРЕЛ:}

1. Струтинська І.В. Десрініції поняття «Цифрова трансфрормація». Причорноморські економічні студії : науковий журнал. 2019. Вип. 48. Ч. 2. С. 91-96.

2. Концепція розвитку цифрової економіки та суспільства України на 2018-2020 роки. URL: https://zakon.rada.gov.ua/laws/show/67-2018-\%D1\%80\#n13 (дата звернення: 20.06.2021).

3. Офріційний сайт державної служби статистики. URL: http://www.ukrstat.gov.ua/ (дата звернення: 10.05.2021).

4. Аналіз регуляторного впливу до проєкту Закону України «Про розвиток інновацій». URL: https://www.me.gov.ua/Documents/Download (дата звернення: 12.05.2021). 
5. Цілі Сталого Розвитку: Україна. URL: https://mepr.gov.ua/files/docs/Національна\%20доповідь\%20 ЦСР\%20України_липень\%202017\%20ukr.pdf (дата звернення: 12.06.2021).

6. Глобальний Інноваційний Індекс 2020. URL: https://www.wipo.int/edocs/pubdocs/en/wipo_pub_gii_2020.pdf (дата звернення: 22.06.2021).

\section{REFERENCES:}

1. Strutynska I.V. (2019) Definitsii poniattia «Tsyfrova transformatsiia» [The definitions of "Digital Transformation"]. Prychornomorski ekonomichni studii: naukovyi zhurnal [Black Sea Economic Studies: a scientific journal], vol. 48, ch. 2, pp. 91-96. (in Ukrainian)

2. Kontseptsiia rozvytku tsyfrovoi ekonomiky ta suspilstva Ukrainy na 2018-2020 roky [The concept of the development of the digital economy and society of Ukraine for 2018-2020]. Available at: https://zakon.rada.gov.ua/laws/ show/67-2018-\%D1\%80\#n13 (accessed 20 June 2021).

3. Ofitsiinyi sait derzhavnoi sluzhby statystyky [The official site of the state statistics service]. Available at: http://www.ukrstat.gov.ual (accessed 10 May 2021).

4. Analiz rehuliatornoho vplyvu do proiektu zakonu ukrainy «Pro rozvytok innovatsii» [Analysis of the regulatory impact on the draft Law Of Ukraine "On the development of innovation"]. Available at: https://www.me.gov.ua/Documents/Download (accessed 12 May 2021).

5. Tsili Staloho Rozvytku: Ukraina [Sustainable development goals: Ukraine]. Available at: https://mepr.gov.ua/ files/docs/Natsionalna\%20dopovid\%20TsSR\%20Ukrainy_lypen\%202017\%20ukr.pdf (accessed 12 June 2021).

6. Hlobalnyi innovatsiinyi indeks 2020 [Global innovation index 2020]. Available at: https://www.wipo.int/edocs/ pubdocs/en/wipo_pub_gii_2020.pdf (accessed 22 June 2021). 